\title{
Pengaruh perbedaan ukuran polen pada penyerbukan buatan terhadap potensi jumlah buah pada tanaman kelapa sawit (Elaeis guinaensis Jacq.)
}

\section{Effect of pollen sizes on number of oil palm (Elaeis guinaensis Jacq.) in artificial pollination}

\author{
Diterima : 12 Desember 2018/Disetujui : 25 Maret 2019 / Dipublikasikan : 31 Maret 2019 \\ CDepartment of Crop Science, Padjadjaran University
}

\begin{abstract}
Decline of oil palm fruit sets impacts on the production of fresh fruit bunches (FFB). This is caused by less effective natural pollination. Objective of this research was to determine the effect of pollen size differences by artificial pollination to the potency of number of fruits per bunch, percentage of success fruit sets, and shapes of oil palm fruits. The method used experimental method. Experimental design was Completely Randomized Design (CRD), which consisted of 2 pollen size treatments and 3 replications. The treatment consisted of pollen size of 10 mesh and 12 mesh, then tested by Duncan's Multiple Range Test. The results showed that the application of pollen size did not significantly affect the number of fruits per bunch, but the percentage of success fruit sets was $>80 \%$, and the shape of fruit was normal. Pollen size from sieves 10 and 12 mesh descriptively homogen and smaller than pollen size from sieves $2-8$ mesh.
\end{abstract}

Keywords: Palm oil • Potential results • Pollen · Fruit

Sari Pembentukan buah tanaman kelapa sawit yang menurun berimbas pada produksi tandan buah segar. Hal ini diakibatkan oleh penyerbukan secara alami yang kurang efektif. Tujuan penelitian ini adalah mengetahui pengaruh perbedaan ukuran serbuk sari terhadap potensi jumlah buah dalam satu tandan, persentase keberhasilan pembentukan buah, dan bentuk buah kelapa sawit dengan cara penyerbukan

\footnotetext{
Dikomunikasikan oleh Mira Ariyanti

Sobari, E. ${ }^{1} \cdot$ A.A. Hasibuan ${ }^{2} \cdot$ M. Subandi ${ }^{2}$

1 Jurusan Agroindustri Politeknik Negeri Subang

2 Jurusan Agroteknologi UIN Sunan Gunung Djati Bandung

Korespondensi: ncesobari@gmail.com
}

buatan. Metode yang digunakan merupakan metode eksperimen dengan rancangan percobaan berupa Rancangan Acak Lengkap, yang terdiri dari 2 perlakuan ukuran serbuk sari dan 3 ulangan. Perlakuan terdiri dari ukuran serbuk sari 10 mesh dan 12 mesh. Pengujian lanjut dilakukan dengan Uji Jarak Berganda Duncan. Hasil penelitian menunjukkan bahwa aplikasi ukuran serbuk sari tidak berpengaruh nyata terhadap jumlah buah terbentuk dalam satu tandan, tetapi persentase keberhasilan pembentukan buah $>80 \%$, dan bentuk buah yang dihasilkan rata-rata buah normal. Ukuran serbuk sari dari saringan 10 dan 12 mesh secara deskriptif lebih kecil serta seragam dibandingkan saringan 2 - 8 mesh.

Kata kunci: Kelapa sawit • Potensi hasil • Polen • Buah

\section{Pendahuluan}

Kelapa sawit (Elaeis guiniensis Jacq.) merupakan salah satu jenis tanaman perkebunan yang penting dan penghasil minyak tertinggi. Luas areal produksi kelapa sawit di Indonesia terus meningkat berdasarkan data dari Departemen Pertanian (2011) produksi CPO (Crude Palm Oil) di Indonesia sebesar 19.844.901 ton dengan luas areal sebesar 8.430.206 ha (Firdaus \& Lubis, 2018). Minyak sawit diproduksi di seluruh dunia karena banyak dibutuhkan untuk konsumsi. Produksi minyak sawit digunakan untuk berbagai macam makanan, kosmetik, produk kebersihan, dan sumber biofuel atau biodiesel (Sobari, et. al., 2018). 
Hasil produksi buah kelapa sawit dipengaruhi oleh proses penyerbukan untuk menghasilkan bakal buah. Pembentukan buah diawali dengan proses polinasi kepala putik oleh serbuk sari melalui penyerbukan sendiri (bantuan angina), serangga penyerbuk, dan manusia yang selanjutnya polen berkecambah dan mencapai bakal biji (Pardal, 2001).

Permasalahan penyerbukan pada tanaman kelapa sawit yaitu kurangnya jumlah bunga jantan sebagai sumber serbuk sari dan kurang efektifnya serangga penyerbuk Elaidobius kamerunicus dalam menyerbuki bunga betina pada musim penghujan (Setyawibawa dan Widiastuti, 1992). Solusi terbaik yang dapat dilakukan adalah dengan penyerbukan buatan.

Pada penyerbukan buatan, serbuk sari harus disaring untuk menentukan ukuran serbuk sari dan dapat memperoleh serbuk sari murni. Menurut Jambak (2011), serbuk sari tanaman kelapa sawit disaring menggunakan saringan dengan ukuran 8-10 mesh.

Serbuk sari memiliki ukuran, bentuk, dan pola lekukan yang beragam, sehingga memungkinkan perbedaan ukuran dan bentuk serbuk sari walaupun berasal dari bunga yang sama (Cartono dan Ibrahim, 2008). Ada kemungkinan perbedaan ukuran serbuk sari yang mempengaruhi potensi jumlah buah tanaman kelapa sawit dalam satu tandan.

Tujuan penelitian ini adalah untuk mengetahui pengaruh ukuran polen terhadap banyaknya buah kelapa sawit yang terbentuk.

\section{Bahan dan Metode}

Penelitian ini dilaksanakan di kebun kelapa sawit rakyat yang terletak pada koordinat $1{ }^{\circ} 41^{\prime}-$ 20 44' Lintang Utara dan 99॰33' - 100'22 Bujur Timur dengan ketinggian $600 \mathrm{~m}$ di atas permukaan laut (dpl), luas lahan 184 meter x 88 meter. Tempat percobaan beralamat di Dusun Pamintasa, Desa Tanjung Siram, Kecamatan Bila Hulu, Kabupaten Labuhan Batu, Provinsi Sumatera Utara. Pelaksanaan penelitian dimulai April - Mei 2017.

Bahan yang digunakan dalam penelitian ini adalah tanaman kelapa sawit (Varietas DxP Yangambi) yang sudah mencapai tahap menghasilkan 2 tahun (TM 2), serbuk sari 0,25 gram/penyerbukan, dan alkohol 70\%. Alat yang digunakan dalam penelitian ini adalah parang (golok), pisau, dodos, tali karet atau tali rafiah, kantung plastik, kertas label, saringan berukuran 2 mesh, 4 mesh, 8 mesh, 6 mesh, 10 mesh dan 12 mesh, botol pulper, selang kecil, higrometer, alat tulis, hand counter, timbangan analitik, dan freezer.

Penelitian ini menggunakan Rancangan Acak Lengkap (RAL). Faktor ukuran serbuk sari yaitu: $\mathrm{a}_{1}=$ ukuran serbuk sari 10 mesh dan $\mathrm{a}_{2}=$ ukuran serbuk sari 12 mesh. Jadi terdapat dua kombinasi perlakuan diulang 3 kali sehingga seluruhnya terdapat 6 perlakuan.

Parameter pengamatan dalam penelitian ini diantaranya:

1) Uji pendahuluan menyaring serbuk sari dengan menggunakan saringan 2 mesh, 4 mesh, 6 mesh, 8 mesh, 10 mesh, dan 12 mesh secara berturut-turut, sehingga dapat diketahui saringan yang sesuai untuk digunakan pada penelitian ini dengan cara melihat serbuk sari yang lolos dan tidak lolos pada penyaringan.

2) Penghitungan jumlah buah tanaman kelapa sawit dalam satu tandan dapat dihitung menggunakan hand counter setelah 15 hari penyerbukan.

3) Perhitungan persentase keberhasilan pembentukan buah (fruit set) dilakukan dengan rumus berikut ini (Raganata, 2006);

4) Bentuk buah pada tanaman kelapa sawit dapat diklasifikasikan menjadi buah normal, abnormal ringan, abnormal berat dan abnormal sangat berat (Gambar 1).

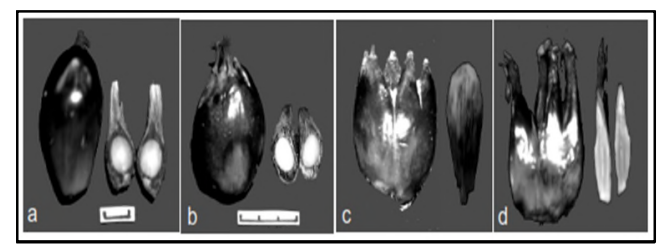

Gambar 1. Tingkat Abnormalitas Buah pada Buah Panen : (A) Buah Normal, (B) Buah Abnormal Ringan, (C) Buah Abnormal Berat, (D) Buah Abnormal Sangat Berat

Sumber : Hetharie dkk., 2007.

Data hasil penelitian dianalisis dengan sidik ragam (ANOVA) berdasarkan model linier Rancangan Acak Lengkap (RAL) pada taraf 5\%. 
Perlakuan yang berpengaruh nyata pada uji sidik ragam kemudian diuji lanjut menggunakan Uji Jarak Berganda Duncan (UJBD) pada taraf $5 \%$ dengan bantuan program DSAASTAT versi 1.101.

\section{Hasil dan Pembahasan}

Uji Pendahuluan. Uji pendahuluan dilakukan pada saringan yang bertujuan untuk menentukan ukuran saringan sebagai alat menyaring serbuk sari sehingga akan diperoleh ukuran serbuk sari tanaman kelapa sawit dalam satuan mesh dan serbuk sari yang diperoleh adalah serbuk sari murni bukan kotoran yang terbawa saat pemanenan serbuk sari.
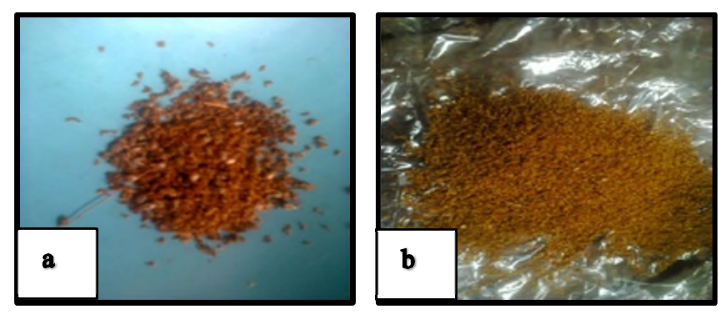

Gambar 2. Hasil Penyaringan Serbuk Sari: (a) 10 mesh (b) 12 mesh

Berdasarkan hasil penyaringan pada saat uji pendahuluan terbukti bahwa serbuk sari yang disaring menggunakan ukuran mesh 2, 4, 6, dan 8 masih bercampur dan ukurannya belum seragam, terutama pada ukuran mesh 2 dan 4 yang masih terbawa dengan kotoran. Pada saat penyaringan selanjutnya diperoleh serbuk sari yang tidak dapat tersaring lagi, dalam artian ukuran serbuk sari sudah seragam, yaitu pada saringan 10 mesh dan 12 mesh seperti pada gambar 2.

Terdapat perbedaan hasil penyaringan dengan menggunakan saringan mesh tersebut disebabkan oleh perbedaan ukuran saringan dan perbedaan ukuran serbuk sari yang di saring. Saringan 10 mesh memiliki lubang jaring yang lebih sedikit dibandingkan dengan 12 mesh, sehingga saringan 10 mesh dapat menyaring ukuran yang lebih besar dibandingkan 12 mesh. Serbuk sari hasil penyaringan 10 mesh lebih kasar dan ukurannya lebih besar dibandingkan serbuk sari hasil penyaringan 12 mesh yang terlihat lebih halus dan ukuran lebih kecil serta homogen (Gambar 2). Hal tersebut sejalan dengan pendapat Cartono dan Ibrahim (2008) yang menyatakan bahwa serbuk sari memiliki ukuran dan bentuk yang beragam dengan pola lekukan yang berbeda sehingga memungkinkan terjadinya perbedaan ukuran dan bentuk serbuk sari walaupun berasal dari bunga yang sama.

Perhitungan Jumlah Buah Terbentuk. Berdasarkan hasil penelitian, perlakuan ukuran serbuk sari berpengaruh nyata terhadap parameter jumlah buah terbentuk. Hal ini terjadi karena serbuk sari merupakan faktor utama penentu proses terbentuknya buah. Solusi untuk meningkatkan pembentukan buah pada tanaman kelapa sawit baru menghasilkan (TM) melalui penyerbukan buatan, dengan cara mengoptimalkan penyerbukan tersebut pada serbuk sari dari bunga jantan ke kepala putik bunga betina (Setyawibawa dan Widyastuti, 1992). Hal ini dapat mengurangi kegagalan penyerbukan dan berimplikasi meningkatnya jumlah buah terbentuk per tandan sebagaimana yang ditunjukkan pada Tabel 1 .

Tabel 1. Pengaruh Ukuran Polen terhadap Jumlah Buah Tanaman Kelapa Sawit.

\begin{tabular}{cc}
\hline Perlakuan & Rata-rata jumlah buah \\
\hline $\mathrm{a}_{1}(10$ mesh $)$ & $268,89 \mathrm{a}$ \\
$\mathrm{a}_{2}(12 \mathrm{mesh})$ & $267,89 \mathrm{a}$ \\
\hline
\end{tabular}

Keterangan : Angka-angka pada kolom yang sama yang diikuti huruf yang sama menunjukkan tidak berbeda nyata menurut Uji Jarak berganda Duncan taraf 5\%.

Tabel 1 menunjukan bahwa ukuran polen tidak berpengaruh terhadap jumlah buah yang terbentuk pada tanaman kelapa sawit. Faktor yang mempengaruhi keberhasilan pembentukan bakal buah diantaranya kerapatan, pola spasial, komposisi pollnator, kelimpahan pollinator, perilaku polinator, kondisi lingkungan pada saat penyerbukan, pemupukan, perkembangan embrio, dan sumber daya yang bisa dipakai untuk pemasakan buah dan benih (Putri \& Pramono, 2013). Namun, jika dilihat dari karakter bentuk serbuk sari 10 mesh seperti gumpalan serbuk sari atau kumpulan serbuk sari yang saling melekat sedangkan pada serbuk sari 12 mesh seperti butiran pasir yang terpisah dari yang lainnya (Gambar 2). Hal ini dapat diasumsikan bahwa hasil penyaringan serbuk sari 10 mesh mengandung banyak butiran serbuk sari dibandingkan serbuk sari hasil penyaringan 12 mesh dan bila jatuh di kepala 
putik bunga betina dapat memberikan potensi jumlah serbuk sari yang lebih banyak pilihan pada proses penyerbukan.

Banyaknya butiran serbuk sari yang terkumpul pada hasil penyaringan 10 mesh dapat mencegah kegagalan pada proses penyerbukan dan berimplikasi pada peningkatan jumlah buah terbentuk satu tandan. Menurut Jambak (2011) pada penyerbukan kelapa sawit secara buatan di PPKS Medan dengan menyaring serbuk sari 8 mesh - 10 mesh akan meningkatan jumlah buah yang terbentuk sampai $80 \%$. Hal ini sesuai dengan pernyataan Widiastuti dan Palupi (2008), bahwa semakin banyak serbuk sari yang digunakan cenderung meningkatkan pembentukan buah normal, berkisar antara $70 \%$ - 76\%, serta menurunkan buah abnormal.

Persentase Keberhasilan Pembentukan Buah. Berdasarkan hasil penelitian, persentase keberhasilan pembentukan buah dapat dilihat pada Gambar 3.

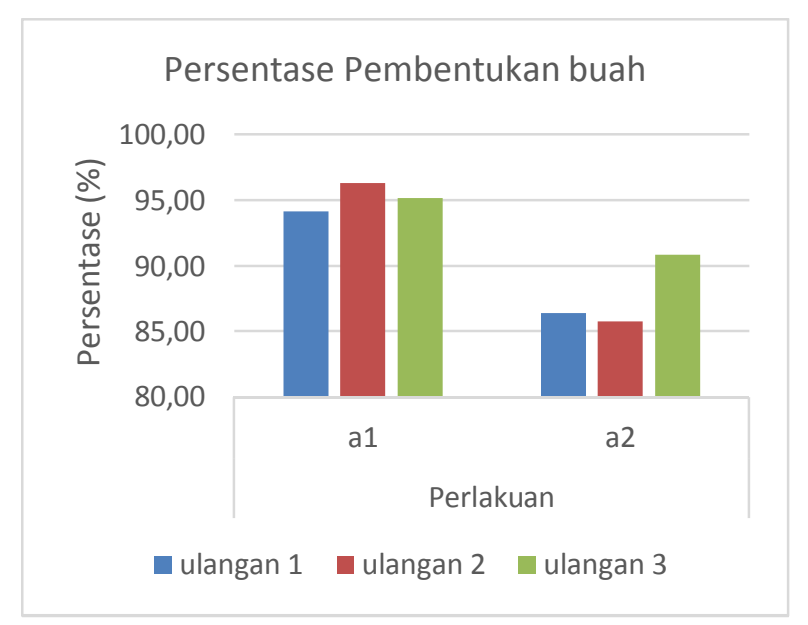

\section{Gambar 3. Diagram Persentase Pembentukan Buah Kelapa Sawit.}

Gambar 3 menggambar bahwa perlakukan $\mathrm{a}_{1}$ memperlihatkan persentase buah yang terbentuk diatas $80 \%$, hal ini menunjukan hasil yang positif. Persentase keberhasilan pembentukan buah setiap tandannya sudah sangat baik. Keberhasilan pembentukan buah dalam proses penyerbukan buatan disebabkan polinator dan serbuk sari yang digunakan. Polinator dalam penyerbukan buatan adalah manusia sehingga dapat mengoptimalkan banyaknya serbuk sari yang digunakan dan jatuhnya serbuk sari ke kepala putik. Serbuk sari yang digunakan adalah serbuk sari yang murni, bukan campuran kotoran yang ikut terbawa saat pemanenan serbuk sari. Serbuk sari merupakan hasil penyaringan saringan 10 mesh dan 12 mesh sehingga dapat mengurangi kegagalan dalam penyerbukan dan meningkatkan persentase buah dalam satu tandan.

Hal tersebut sesuai dengan yang dilaporkan Jambak (2011), bahwa peningkatan persentase keberhasilan pembentukan buah pada tanaman kelapa sawit akan tercapai jika dilakukan penyerbukan buatan dengan menyaring serbuk sari menggunakan saringan 8-10 mesh, peningkatan persentase buah dilaporkan sebesar $80 \%$. Padahal menurut Setyawibawa dan Widyastuti (1992), tanaman kelapa sawit varietas Yangambi (dura $x$ pisifera) dengan penyerbukan alami memiliki persentase keberhasilan pembentukan buah per tandan hanya 56,6\% saja. Hal ini memperjelas bahwa dengan metode penyerbukan buatan dan menyaring serbuk sari dengan saringan 10 mesh dan 12 mesh dapat meningkatkan persentase keberhasilan pembentukan buah kelapa sawit diatas $80 \%$.

Selain itu, terdapat faktor pendukung yang menunjang terjadinya peningkatan persentase keberhasilan pembentukan buah yaitu suhu dan kelembaban udara di tempat penelitian serta sinar matahari diperlukan sebagai sarana proses fotosintesis tanaman yang memproduksi karbohidrat untuk pembentukan bunga dan buah. Lama penyinaran matahari akan mempengaruhi suhu dan kelembaban udara di tempat penelitian. (Sobari \& Fathurohman, 2017).

Suhu di tempat penelitian berkisar 22,2 $31,05{ }^{\circ} \mathrm{C}$ dengan kelembaban udara berkisar 57 - 90\%. Suhu optimum untuk keberlangsungan penyerbukan tanaman kelapa sawit berkisar $24^{\circ} \mathrm{C}-28^{\circ} \mathrm{C}$ dengan kelembaban udara optimum berkisar $80 \%$ yang merupakan faktor penting dalam menunjang pertumbuhan (Fauzi et al. 2012).

Hal ini sesuai dengan pernyaataan Turner dan Gillbanks (1974) yang menyatakan bahwa suhu tinggi dapat meningkatkan jumlah serbuk sari di atmosfir. Selain itu juga, kelembaban yang tinggi dapat meningkatkan kelembaban putik bunga betina sehingga penangkapan serbuk sari meningkat serta akan meningkatkan jumlah buah yang terbentuk.

Pada percobaan ini dapat diasumsikan bahwa peningkatan persentase keberhasilan pembentukan buah (fruit set) hingga diatas $80 \%$ 
bukan saja disebabkan perlakuan-perlakuan dalam percobaan seperti penyerbukan secara buatan dan penyaringan serbuk sari dengan saringan 10 mesh dan 12 mesh, tetapi juga ditunjang oleh faktor lingkungan yang optimal pada saat penelitian seperti suhu dan kelembaban dapat mempengaruhi persentase hasil (Sobari, Fathurohman, \& Hadi, 2018)

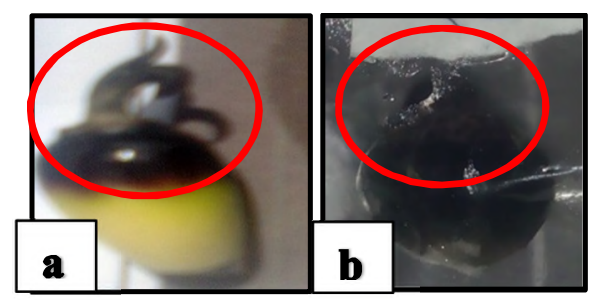

Gambar 4. Bentuk Buah : (a) Normal (Nml); (b) Abnormal Ringan (AbR)

Bentuk Buah. Berdasarkan Gambar 4 di atas yang menunjukkan bahwa gambar 4a, memperlihatkan perlakukan selama penelitian menghasilkan bentuk buah yang normal kecuali pada pada gambar $4 \mathrm{~b}$ yang menghasilkan bentuk buah abnormal ringan dalam satu tandan buah, bahkan pada tandan buah lain dalam satu pohon tersebut keseluruhan buahnya abnormal ringan. Penyebab abnormalitas karena adanya perubahan susunan oligonukleotida pada untaian DNA yang terjadi secara acak, dan perbedaan pada masing-masing klon (Mathius, Bangun, \& Bintang, 2001). Hal ini ditandai dengan adanya karpel tambahan pada bagian ujung buah sehingga dapat diketahui terjadinya buah yang tidak normal disebabkan genetik tanaman tersebut. karena faktor genetik pula dapat mempengaruhi bentuk, serta ukuran pada buah (Sobari \& Wicaksana, 2017)

Hal tersebut dibenarkan Hetharie et al., (2007) yang menyatakan bahwa buah abnormal sering terjadi pada tanaman kelapa sawit hasil kultur jaringan. Kriteria buah kelapa sawit digolongkan atas empat jenis yaitu; (1) normal (Nml) dengan ciri tidak ada karpel tambahan, (2) abnormal ringan (AbR) dengan ciri ada karpel tambahan namun karpel tambahan hanya nampak pada ujung buah, (3) abnormal berat $(\mathrm{AbB})$ dengan ciri karpel tambahan dari bagian ujung sampai bagian tengah, (4) abnormal sangat berat (AbSB) dengan ciri karpel tambahan terpisah dari karpel utama, dimulai dari ujung sampai sepertiga dari pangkal buah demikian juga antar karpel tambahan. Tanaman kelapa sawit yang menghasilkan bunga betina abnormal juga menghasilkan bunga jantan abnormal, sebaliknya tanaman dengan bunga betina normal mempunyai bunga jantan normal (Hetharie et al., 2007). Begitu juga dengan buahnya, jika bunga betina normal biasanya menghasilkan buah normal pula kecuali terjadi gangguan aktifitas fisiologi tanaman saat perkembangan buah, seperti terjadi musim kemarau yang cukup panjang.

\section{Kesimpulan dan Saran}

Kesimpulan:

1. Perbedaan ukuran serbuk sari (10 mesh dan 12 mesh) tidak memberikan pengaruh yang nyata, namun secara deskriptif lebih baik daripada 2 mesh sampai 8 mesh terhadap parameter jumlah buah terbentuk dalam satu tandan,

2. Persentase keberhasilan pembentukan buah pada perlakuan saringan 10 dan 12 mesh mencapai lebih dari $80 \%$, dan tidak berpengaruh nyata terhadap parameter bentuk buah.

Saran :

1. Perlu melakukan pengukuran suhu, kelembaban, curah hujan, dan lama penyinaran sehingga diketahui seberapa sebesar faktor lingkungan mempengaruhi pembentukan buah tanaman kelapa sawit.

2. Perlu melakukan pengujian kualitas buah terhadap buah kepala sawit yang telah siap panen sehingga diketahui kualitas buah yang dihasilkan dari percobaan.

\section{Ucapan Terima Kasih}

Kami ucapkan terimakasih yang sebesarbesarnya kepada Bapak Fahami Ansori Hasibuan sebagai pemilik lahan kelapa sawit rakyat yang telah memberikan izin melakukan penelitian ini .

\section{Daftar Pustaka}

Cartono dan Ibrahim, A. (2008). Anatomi Tumbuhan. Bandung: Prisma press.

Fauzi, Y., Widyastuti, Y.E., Satyawibawa, I., Paeru, R.H., (2012). Kelapa Sawit. Penebar Swadaya $47 \mathrm{p}$. 
Firdaus, M., \& Lubis, I. (2018). Analisis Produksi Kelapa Sawit (Elaeis Guineensis Jacq.) Di Kebun Buatan, Kabupaten Pelalawan, Riau. Bul. Agrohorti, 6(2), 281-286.

Hetharie, H., A.Wattimena, G., S, M. T., Aswidinnoor, H., Toruan-Mathius, N., \& Ginting, G. (2007). Karakterisasi Morfologi Bunga dan Buah Abnormal ( Elaeis guineensis, Jacq ) Tissue Culture-Derived Plants. Bul. Agron, 57(35), 50-57.

Mathius, N. T., Bangun, S. I. I., \& Bintang, M. (2001). Analisis abnormalitas tanaman kelapa sawit ( Elaeis guineensis Jacq ) hasil kultur jaringan dengan teknik Random Amplified Polymorphic DNA ( RAPD ). Menara Perkebunan, 69(2), 58-70.

Pardal, S. J. (2001). Pembentukan Buah Partenokarpi melalui Rekayasa Genetika. Buletin AgroBio, 4(2), 45-49.

Putri, K. P., \& Pramono, A. A. (2013). Perkembangan Bunga, Buah dan Keberhasilan Reproduksi Jenis Saga ( Adenanthera pavonina L.). Penelitian Hutan Tanaman, 10(3), 147-154.

Sobari, E., \& Fathurohman, F. (2017). Efektivitas Penyiangan Terhadap Hasil Tanaman Wortel (Daucus carota L.) Lokal Cipanas Bogor. Jurnal Biodjati, 1(2), 1-8. https://doi.org/https://doi.org/10.15575 /biodjati.v2i1.1292

Sobari, E., Fathurohman, F., \& Hadi, M. A. (2018). Karakter Pertumbuhan Kacang Tanah (Arachis hypogaea L.) dengan Pemanfaatan Kompos Limbah Baglog Jamur dan Kotoran Domba. Agrin, 22(2), 116-122.

https://doi.org/http://dx.doi.org/10.208 84/1.agrin.2018.22.2.447

Sobari, E., Hasibuan, A. A., Subandi, M., \& Rusli, M. D. (2018). Peningkatan Buah Kelapa Sawit (Elaeis Guinensis Jacq ) dengan Memanfaatkan Ukuran Pollen dan Waktu dalam Penyerbukan Buatan. Zuriat, 29(November), 62-66.

Sobari, E., \& Wicaksana, N. (2017). Keragaman Genetik dan Kekerabatan Genotip Kacang Bambara (Vigna subteranea L.) Lokal Jawa Barat. Jurnal Agro, IV(2), 90-96. https://doi.org/https://doi.org/10.15575 $/ 1654$

Turner, P. D. \& Gillbanks, R. A. (1974) Oil palm cultivation and management, Incorporated Society of Planters. 2(51) : 262 - 263.

Widiastuti, A. L. F. I. N., \& Palupi, E. R. (2008). Viabilitas serbuk sari dan pengaruhnya terhadap keberhasilan pembentukan buah kelapa sawit (Elaeis guineensis Jacq.). Biodiversitas, 9(1), 35-38. 